\title{
Assessment of Hematotoxicity and Genotoxicity among paint Workers in Assiut Governorate: a case control study
}

\author{
Nahed Abdel Maksoud ${ }^{1 *}$, Khaled Abdel Aal ${ }^{1}$, Nagwa Ghandour ${ }^{1}$, Mona El-Baz $^{2}$ and Eman Shaltout ${ }^{1}$
}

\begin{abstract}
Background: Occupational exposures to hazardous chemicals in paints cause serious health hazards in painters. The present study was designed to evaluate the possibility of hematotoxic and genotoxic effects of paint chemicals among painters in Assiut Governorate, Egypt. In addition the role of oxidative stress and apoptosis in mechanism of such toxic effects were studied.

Methods: A case control study was performed on 50 male painters and 50 non-exposed healthy subjects, who were included as a control group after informed consent. Venous blood samples were obtained and analyzed for determination of total and differential blood count as hematotoxic markers as well as serum malondialdehyde (MDA) as an oxidant stress markers and total antioxidant enzymes. In addition, human B-cell lymphoma-2 (BCl-2), caspase-3 and 8-hydroxyguanosine (8-OHdG) were assayed as markers of apoptosis and genotoxicity.
\end{abstract}

Results: There was a statistically significant difference between paint workers and controls as regard total and differential blood count, serum MDA and total anti-oxidant levels. Also, statistical significant differences in caspase-3, Bcl-2 levels and 8-OHdG were observed.

Conclusions: Chronic occupational exposure to paints increased the risk of hematotoxicity and genotoxicity in painters. Oxidative stress and apoptosis play a major role in such mechanism. Periodic medical examination and application of protective devices is necessary.

Keywords: Hematotoxicity, Genotoxicity, Oxidative stress, Apoptosis, Paints

\section{Introduction}

Paint products contain many chemical compounds like pigments, extenders, binders, additives and solvents (toluene, xylene, ketones, alcohols, esters, and glycol ethers). Toxicity of these products depends on the types of pigments and solvents used in its manufacture (Scélo et al. 2009).Paint solvents are volatile at room temperature. Paint workers are exposed to these chemicals by inhalation (Zaidi et al. 2007).

Several studies have investigated whether occupational exposure to paints in general is associated with several adverse health effects such as neurological diseases, hearing loss, renal diseases, skin allergies, hepatic, as well as

\footnotetext{
* Correspondence: n.abdelmaksoud@yahoo.com

'Department of Forensic medicine and Clinical toxicology, Assiut University

Faculty of Medicine, Asyut, Egypt

Full list of author information is available at the end of the article
}

respiratory diseases (Chen et al. 1999; Rabinowitz et al. 2008; Kaukiainen et al. 2004; Park et al. 2006; de Oliveira et al. 2011).

Organic solvents in paints and their metabolites are known to be hematotoxic, they are known to have a deleterious effect on bone marrow; these effects may result in a decreased production of red blood cells, white blood cells, and platelets. Therefore, the clinical manifestations of these organic solvents range widely from anemia to leukemia (Kamal and Malik 2012).

Besides hematotoxicity, de Oliveira et al. (2011) reported higher values of chromosomal aberrations (CAs), sister chromatid exchange (SCE) and DNA damage in leukocytes in workers exposed to paints. The authors also described an increase in micro nuclei (MN) in peripheral lymphocytes and in oral mucosa cells. 
Paint solvents express these toxic effects on hematopoietic and genetic systems by generation of reactive oxygen species (ROS) that were found to induce cell damage through the increase in the level of lipid peroxidation, decreased activities of antioxidant enzymes and generation of free radicals (Valko et al. 2007). Oxygen free radicals can induce a variety of DNA damage, including DNA single and double strand breaks and base modifications; they are thought to be involved not only in the mechanisms of several diseases but also, in the mechanism of ageing and in carcinogenesis (Lobo et al. 2010).

These chemicals are involved in hydroxylation of the deoxyguanosine residue in DNA. This seems to proceed via generation of an oxygen radical, such as the hydroxyl radical, resulting in the formation of 8-hydroxydeoxyguanosine (8-OHdG). 8-hydroxy-deoxyguanosine is by far the most studied marker of oxidative DNA damage and the most useful marker used as a precursor of genome instability (Anetor 2010).

Another important mechanism implicated in hematotoxicity and genotoxicity is programmed cell death (apoptosis). Apoptosis plays a very important role in regulating a variety of diseases that may result from an abnormal ratio of pro- and anti-apoptotic factors (Glantz et al. 2006). Defective apoptosis contributes to mutagenesis and carcinogenesis (Hoeijmakers 2009).

Caspases are a family of cysteine proteases that play essential roles in apoptosis. Caspase-3 is the key member of effector caspases (Yuan and Horvitz 2004). B-cell leukemia/lymphoma2 (Bcl-2) is the founding member of the Bcl-2 family of apoptosis regulator proteins. Bcl-2 proteins interact with each other to promote and inhibit apoptosis (Yang et al. 1996).

\section{Aim of the work}

The objectives of the present study were to evaluate the health hazards after exposure to paints among Assiut house painters (roller and brush painters), including evaluations of hematotoxicity and genotoxicity in peripheral blood. This was achieved by measuring the increase in the level of oxidative stress by malondialdehyde activity and total anti-oxidant capacity that restore the cellular defense mechanism and block lipid peroxidation. Caspase-3 and human (Bcl-2) proteins were measured to assay the interaction with each other to promote or inhibit apoptosis, the assay of 8-hydroxy-deoxyguanosine marker was used as a precursor of genome instability and DNA damage.

\section{Methods}

\section{Study population}

This case control study was conducted on 50 male paint workers (exposed group) in Assiut governorate during the period from January 2015 to January 2016. The study was carried out in Assiut University Hospitals and Biochemistry
Department, Faculty of Medicine, Assiut University. Exposed workers age ranged from 23 to 55 years old and had work experience that ranged from one to 35 years. Each worker was interviewed and the relevant information was recorded in a special questionnaire including age, residence, type of work, duration of work, number of hours worked per day, smoking habit whether cigarette or "water-pipe" (number/day and duration), socioeconomic status, level of education, previous history of exposure to hazardous chemicals and use of protective measures during work (mask, gloves and protective clothes).

The exposed workers were subjected to routine clinical examination and laboratory investigations including complete blood picture, Samples were collected from the non-fasting workers within $2 \mathrm{~h}$ after a work day. Workers working for less than 1 year were excluded from the study. It was ascertained that none of those workers had blood diseases and they did not regularly consume drugs with potential hematotoxicity: Workers with parasite infestation as anklystoma or blood losing diseases as piles were excluded. Workers were found to have marked degree of pallor. The same conditions and investigations were carried out in 50 male healthy control subjects. They were chosen from persons attending the blood bank of Assiut University Hospital as blood donors. They were matched for age and sex with the workers but without history of exposure to paints. Samples were collected from the non-fasting controls.

\section{Sample collection and biochemical analysis}

Random blood samples $(10 \mathrm{ml})$ were collected from each participant in both groups by venipuncture in plain sterile tubes. Two milliliters of blood were taken from each sample in another tube for complete blood picture analysis.

The remaining of each sample $(8 \mathrm{ml})$ was subjected to centrifugation at $4000 \mathrm{rpm}$ for $15 \mathrm{~min}$ and the resulting serum was separated and kept frozen at $-20 \mathrm{C}^{\circ}$.

Tissue Malondialdehyde was measured colorimetrically using Diagnostic and Research Reagents of Biodiagnostic, Egypt (CAT. No.; MD 25 29). The reagents were supplied in the form of chromogen, enzyme-buffer and standard kit using the method of Satoh et al. (1978) as modified by Ohkawa et al. (1979).

Serum was analyzed for total antioxidant capacity by colorimetric method using Diagnostic and Research Reagents of Biodiagnostic, Egypt (CAT. No.; TA 25 13). The reagents were supplied in the form of chromogen, enzyme-buffer and standard kit using the method of Koracevic et al. (2001) for total antioxidant capacity.

Human Caspase 3 (Casp-3) was determined with an ELISA kit to form antibody-antigen-enzyme complex measured by spectrophotometric method at a wave length of $450 \mathrm{~nm}$. The kit was supplied by WKEA MED SUPPLIES CORP, China using the method of Xu et al. (2012). 
Human B-cell Leukemia/lymphoma2 (Bcl-2) and Human 8-Hydroxy-deoxyguanosine (8-OHdG) levels were determined quantitatively exactly as described by Hyun et al. (2013) and Sova et al. (2010) respectively. The kits supplied by Glory Science Co., Ltd. cat n. TX 78840, USA. The kits use a monoclonal antibody-based enzyme-linked immunosorbent assay.

\section{Statistical analysis}

The collected data were reviewed and analyzed using the Statistic Package for Social Science Version 22, Chicago, USA. Data were summarized according to the case-control design. The Mann Whitney non-parametric test was used to compare the mean of the two groups, the Chi-square test was used to compare qualitative data of the same group. Studying the relationship between variables was done using Spearman correlation.

\section{Ethical considerations}

The study was done after approval from Research and Ethical committee of Faculty of Medicine, Assiut University. Informed consent was taken from all individuals who participated in the study. Confidentiality of the data was guaranteed.

\section{Results}

The demographic characteristics of the two studied groups (controls and exposed workers) are presented in Table 1. All the male participants are almost of the same age $(30.28 \pm 9.38,32.74 \pm 10.42$ respectively). The mean average of daily paint exposed time (hours) was $6.7 \pm 1.45$ among the exposed workers. Regarding smoking habits, $44 \%$ of the workers were found to be smokers compared with $30 \%$ of the controls $(p=0.147)$. None of the workers was found to use any type of self-protective equipment. They had poor socio-economic backgrounds and low levels of education.

General examination of the paint workers showed highly significant increase in the number and percentage

Table 1 Demographic characteristics of the study groups

\begin{tabular}{|c|c|c|c|}
\hline Characteristic & & $\begin{array}{l}\text { Controls } \\
(N=50)\end{array}$ & $\begin{array}{l}\text { Workers } \\
(N=50)\end{array}$ \\
\hline Age (years) & $\begin{array}{l}\text { Mean } \pm \text { S.E. } \\
\text { Range }\end{array}$ & $\begin{array}{l}30.28 \pm 9.38 \\
21-46\end{array}$ & $\begin{array}{l}32.74 \pm 10.42 \\
20-57\end{array}$ \\
\hline $\begin{array}{l}\text { Average working time } \\
\text { (years) }\end{array}$ & $\begin{array}{l}\text { Mean } \pm \text { S.E. } \\
\text { Range }\end{array}$ & $-\overline{-}$ & $\begin{array}{l}17.26 \pm 1.53 \\
1-35\end{array}$ \\
\hline $\begin{array}{l}\text { Daily paint exposure time } \\
\text { (hours) }\end{array}$ & $\begin{array}{l}\text { Mean } \pm \text { S.E. } \\
\text { Range }\end{array}$ & - & $\begin{array}{l}6.7 \pm 1.45 \\
4-8\end{array}$ \\
\hline Smokers/non smokers & $N$ & $15 / 35$ & $22 / 28$ \\
\hline $\begin{array}{l}\text { Use of individual protection } \\
\text { equipment }\end{array}$ & Percentage (\%) & - & 00 \\
\hline
\end{tabular}

of workers who had arthralgia, pallor, fatigue, and dyspnea compared to controls (Table 2).

On examination, 25 (50\%) of workers had poly arthralgia, 20 workers (40\%) had mild pallor, 16 (32\%) expressed having fatigue and ten workers (20\%) had dyspnea grade 2 (difficulty in breathing is felt when walking up a slope or on the stairs). The percentage of paint workers who had numbness in both hands was $10 \%$ (5 painters), two (4\%) had mild fever and easy tendency to bleed form gums and nose was also, observed in two (4\%) workers.

Table 3 represents the effect of occupational exposure to paints on different red blood cell (RBC) parameters in workers compared to controls. A highly significant decrease in the total RBCs count was observed in workers occupationally exposed to paints (mean was $4.83 \pm 0.06$ ) compared to the control group $(5.14 \pm 0.06)$. A significant decrease in the hemoglobin (HGB) and hematocrit value (HCT) was observed in workers compared to control group. Mean corpuscular hemoglobin concentration $(\mathrm{MCHC})$ was highly significantly decreased in workers group (32.87 \pm 0.30$)$ compared to control group $(34.06 \pm 0.18)$. No significant changes were observed regarding mean corpuscular volume $(\mathrm{MCV})$, mean corpuscular hemoglobin $(\mathrm{MCH})$ and platelets blood count (PLT).

Table 4 represents the effect of occupational exposure to paints on white blood cells parameters (WBC) in workers compared to the controls. A significant decrease in the mean values of WBCs count observed in occupationally exposed workers compared to controls (5.71 \pm 0.30 and $6.32 \pm 0.20$ respectively), occupational exposures to paints on basophils count expressed a highly significant increase in workers compared to controls with mean values $(0.60 \pm 0.04$ and $0.47 \pm 0.01$ respectively). No significant changes were observed as regard neutrophils, lymphocytes, monocytes and eosinophils count and also, regarding presence of atypical lymphocytes and large immature cells in workers compared to controls.

Table 2 Clinical data of the general examination of exposed workers compared to controls

\begin{tabular}{|c|c|c|c|c|c|}
\hline \multirow[t]{2}{*}{ Clinical data } & \multicolumn{2}{|c|}{$\begin{array}{l}\text { Control group } \\
(N=50)\end{array}$} & \multicolumn{2}{|c|}{$\begin{array}{l}\text { Exposed workers } \\
(N=50)\end{array}$} & \multirow[t]{2}{*}{$P$-value } \\
\hline & $\overline{\mathrm{N}}$. & $\%$ & $\bar{N}$. & $\%$ & \\
\hline Arthralgia & 0 & 0.0 & 25 & 50 & $<0.001^{* * *}$ \\
\hline Pallor & 0 & 0.0 & 20 & 40 & $<0.001^{* * *}$ \\
\hline Fatigue & 0 & 0.0 & 16 & 32 & $<0.001^{* * *}$ \\
\hline Dyspnea & 0 & 0.0 & 10 & 20 & $0.001^{* *}$ \\
\hline Bleeding tendency & 0 & 0.0 & 2 & 4 & 0.475 \\
\hline Fever & 0 & 0.0 & 2 & 4 & 0.475 \\
\hline $\begin{array}{l}\text { Numbness of the } \\
\text { extremities }\end{array}$ & 0 & 0.0 & 5 & 10 & 0.066 \\
\hline
\end{tabular}

${ }^{* *} P$-value $\leq 0.01$ high significant, ${ }^{* * *} P$-value $\leq 0.001$ highly significant $N$ number, $\%$ percentage 
Table 3 Hematological indices in exposed workers compared with healthy controls

\begin{tabular}{|c|c|c|c|c|}
\hline Parameters & & $\begin{array}{l}\text { Controls } \\
(N=50)\end{array}$ & $\begin{array}{l}\text { Workers } \\
(N=50)\end{array}$ & $P$-value \\
\hline $\begin{array}{l}\text { Red blood cells } \\
\text { million cells/ } / \mu l\end{array}$ & $\begin{array}{l}\text { Mean } \pm \text { SE } \\
\text { Range }\end{array}$ & $\begin{array}{l}5.14 \pm 0.06 \\
5.01-5.85\end{array}$ & $\begin{array}{l}4.83 \pm 0.06 \\
4.09-4.85\end{array}$ & $<0.001^{* * *}$ \\
\hline $\begin{array}{c}\text { Hemoglobin } \\
\text { grams/dL }\end{array}$ & $\begin{array}{l}\text { Mean } \pm S E \\
\text { Range }\end{array}$ & $\begin{array}{l}14.18 \pm 0.10 \\
12.9-16\end{array}$ & $\begin{array}{l}12.8 \pm 0.15 \\
11.1-13\end{array}$ & $0.030^{*}$ \\
\hline $\begin{array}{c}\text { Hematocrit } \\
\text { Percent }\end{array}$ & $\begin{array}{l}\text { Mean } \pm \text { SE } \\
\text { Range }\end{array}$ & $\begin{array}{l}42.83 \pm 0.39 \\
36.7-50.2\end{array}$ & $\begin{array}{l}37.15 \pm 0.56 \\
24-50.2\end{array}$ & $0.027^{*}$ \\
\hline Mean corpuscular volume(FL) & $\begin{array}{l}\text { Mean } \pm S E \\
\text { Range }\end{array}$ & $\begin{array}{l}88.31 \pm 0.57 \\
80-97.5\end{array}$ & $\begin{array}{l}86.55 \pm 0.86 \\
69-97.5\end{array}$ & 0.226 \\
\hline $\begin{array}{l}\text { Mean corpuscular hemoglobin } \\
\text { picograms/cell }\end{array}$ & $\begin{array}{l}\text { Mean } \pm S E \\
\text { Range }\end{array}$ & $\begin{array}{l}28.72 \pm 0.18 \\
27-32\end{array}$ & $\begin{array}{l}28.67 \pm 0.35 \\
20.9-33.8\end{array}$ & 0.576 \\
\hline Mean corpuscular hemoglobin concentration ( $\mathrm{g} / \mathrm{dL})$ & $\begin{array}{l}\text { Mean } \pm \text { SE } \\
\text { Range }\end{array}$ & $\begin{array}{l}34.06 \pm 0.18 \\
31.3-36\end{array}$ & $\begin{array}{l}32.87 \pm 0.30 \\
25.8-37.6\end{array}$ & $0.001^{* *}$ \\
\hline Platelet count (billion/L) & $\begin{array}{l}\text { Mean } \pm \text { SE } \\
\text { Range }\end{array}$ & $\begin{array}{l}236.76 \pm 7.89 \\
150-348\end{array}$ & $\begin{array}{l}233.36 \pm 8.88 \\
30-348\end{array}$ & 0.915 \\
\hline
\end{tabular}

$N$ number

${ }^{*} P$-value $\leq 0.05$ significant, ${ }^{* *} P$-value $\leq 0.01$ high significant, ${ }^{* * *} P$-value $\leq 0.001$ highly significant

Highly significant and significant changes in all the levels of biochemical parameters were observed in workers occupationally exposed to paints in comparison with the control group (Table 5).

The effects of exposure to paint chemicals on the oxidative stress bioindices in workers group showed a highly significant increase in the mean value $(6.53 \pm 0.20)$ of malondialdehyde compared to the control group (3.83 \pm 0.16). The results suggest that the levels of total antioxidants in workers were highly significantly decreased when compared to the control group.

The results represent the effect of occupational exposure to paint chemicals on apoptotic marker, as the mean value of caspase-3 was significantly increased in workers in comparison with in the control group. As regards the effects on anti-apoptotic markers, the mean level of Human Bcl-2 show highly significant decrease in comparison with the mean levels in control group. The results also, clarified the effects of paints on oxidative DNA damage. DNA damage measured by Human 8-Hydroxy-deoxyguanosine (8-OHdG) which was highly significantly increased in comparison with control group.

The effect of age on different hematological and biochemical markers in occupationally exposed workers showed no significant difference when compared with controls (Table 6).

Table 4 Effect of occupational exposure to paints on WBC parameters in exposed workers compared to controls

\begin{tabular}{|c|c|c|c|c|}
\hline WBCs parameter & & $\begin{array}{l}\text { Controls } \\
(N=50)\end{array}$ & $\begin{array}{l}\text { Workers } \\
(N=50)\end{array}$ & $P$-value \\
\hline 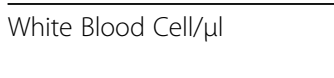 & $\begin{array}{l}\text { Mean } \pm \text { SE } \\
\text { Range }\end{array}$ & $\begin{array}{l}6.32 \pm 0.20 \\
3.4-9.7\end{array}$ & $\begin{array}{l}5.71 \pm 0.30 \\
2.8-15.1\end{array}$ & $0.019^{*}$ \\
\hline Neutrophils (\%) & $\begin{array}{l}\text { Mean } \pm \text { SE } \\
\text { Range }\end{array}$ & $\begin{array}{l}56.04 \pm 0.63 \\
50-63\end{array}$ & $\begin{array}{l}53.24 \pm 1.64 \\
21.2-80\end{array}$ & 0.192 \\
\hline Lymphocytes(\%) & $\begin{array}{l}\text { Mean } \pm \text { SE } \\
\text { Range }\end{array}$ & $\begin{array}{l}32.24 \pm 1.13 \\
22-45\end{array}$ & $\begin{array}{l}33.50 \pm 1.56 \\
13.4-54\end{array}$ & 0.522 \\
\hline Monocytes (\%) & $\begin{array}{l}\text { Mean } \pm \text { SE } \\
\text { Range }\end{array}$ & $\begin{array}{l}8.84 \pm 0.24 \\
1-11.8\end{array}$ & $\begin{array}{l}8.46 \pm 0.31 \\
3-14.7\end{array}$ & 0.148 \\
\hline Eosinophils(\%) & $\begin{array}{l}\text { Mean } \pm \text { SE } \\
\text { Range }\end{array}$ & $\begin{array}{l}1.36 \pm 0.03 \\
1-1.5\end{array}$ & $\begin{array}{l}2.19 \pm 0.34 \\
1-15.9\end{array}$ & 0.449 \\
\hline Basophils (\%) & $\begin{array}{l}\text { Mean } \pm \text { SE } \\
\text { Range }\end{array}$ & $\begin{array}{l}0.47 \pm 0.01 \\
0.2-1.5\end{array}$ & $\begin{array}{l}0.60 \pm 0.04 \\
0.3-0.6\end{array}$ & $0.006^{* *}$ \\
\hline Atypical Lymphocytes (ALYs) & $\begin{array}{l}\text { Mean } \pm \text { SD } \\
\text { Range }\end{array}$ & $\begin{array}{l}1.03 \pm 0.21 \\
0.8-1.4\end{array}$ & $\begin{array}{l}1.73 \pm 0.41 \\
0.8-2.4\end{array}$ & 0.096 \\
\hline Large immature cells (LICs) & $\begin{array}{l}\text { Mean } \pm \text { SD } \\
\text { Range }\end{array}$ & $\begin{array}{l}1.17 \pm 0.37 \\
0.7-1.9\end{array}$ & $\begin{array}{l}1.42 \pm 0.57 \\
0.7-2.5\end{array}$ & 0.070 \\
\hline
\end{tabular}

Atypical Lymphocytes: include large lymphocytes, activated lymphocytes, lymphoid cells, and small lymphocytes

Large immature cells: include myelocytes, promyelocytes, metamyelocytes, and large blasts

$N$ number, $S E$ standard error, SD standard deviation

${ }^{*} P$-value $\leq 0.05$ significant, ${ }^{* *} P$-value $\leq 0.01$ high significant 
Table 5 Biochemical markers in occupationally exposed group versus control group

\begin{tabular}{|c|c|c|c|c|}
\hline Bioindicies & & $\begin{array}{l}\text { Controls } \\
(N=50)\end{array}$ & $\begin{array}{l}\text { Workers } \\
(N=50)\end{array}$ & $P$-value \\
\hline $\begin{array}{l}\text { Malondialdehyde } \\
\mathrm{nmol} / \mathrm{mL}\end{array}$ & $\begin{array}{l}\text { Mean } \pm \text { SE } \\
\text { Median(Range) }\end{array}$ & $\begin{array}{l}3.83 \pm 0.16 \\
3.5(2.4-8.2)\end{array}$ & $\begin{array}{l}6.53 \pm 0.20 \\
6.9(3.9-9.1)\end{array}$ & $<0.001^{* *}$ \\
\hline $\begin{array}{l}\text { Total Anti-Oxidant } \\
\mathrm{mM} / \mathrm{L}\end{array}$ & Mean \pm SE Median(Range) & $\begin{array}{l}0.21 \pm 0.01 \\
0.22(0.01-0.51)\end{array}$ & $\begin{array}{l}0.16 \pm 0.01 \\
0.15(0.01-0.50)\end{array}$ & $<0.001^{* * *}$ \\
\hline $\begin{array}{l}\text { Human Caspase-3 } \\
\mathrm{pg} / \mathrm{mL}\end{array}$ & $\begin{array}{l}\text { Mean } \pm \text { SE } \\
\text { Median(Range) }\end{array}$ & $\begin{array}{l}0.46 \pm 0.03 \\
0.40(0.12-0.93)\end{array}$ & $\begin{array}{l}0.67 \pm 0.06 \\
0.51(0.22-1.65)\end{array}$ & $0.031^{*}$ \\
\hline $\begin{array}{l}\text { Human Bcl-2 } \\
\mathrm{ng} / \mathrm{mL}\end{array}$ & $\begin{array}{l}\text { Mean } \pm \text { SE } \\
\text { Median(Range) }\end{array}$ & $\begin{array}{l}0.50 \pm 0.14 \\
0.0(0.0-2.8)\end{array}$ & $\begin{array}{l}0.05 \pm 0.05 \\
0.0(0.0-2.6)\end{array}$ & $0.004^{* *}$ \\
\hline $\begin{array}{l}\text { Human }(8-\mathrm{OHdG}) \\
\mathrm{ng} / \mathrm{mL}\end{array}$ & $\begin{array}{l}\text { Mean } \pm \text { SE } \\
\text { Median(Range) }\end{array}$ & $\begin{array}{l}0.21 \pm 0.02 \\
0.0(0.0-0.25)\end{array}$ & $\begin{array}{l}0.60 \pm 0.21 \\
0.0(0.0-4.8)\end{array}$ & $0.006^{* *}$ \\
\hline
\end{tabular}

$N$ number

${ }^{*} P$-value $\leq 0.05$ significant, ${ }^{* *} P$-value $\leq 0.01$ high significant, ${ }^{* * *} P$-value $\leq 0.001$ highly significant

Table 6 Effect of age on the different hematological and biochemical parameters in workers compared to controls

\begin{tabular}{|c|c|c|c|c|}
\hline \multirow[t]{2}{*}{ Parameter } & \multicolumn{2}{|c|}{ Controls } & \multicolumn{2}{|c|}{ Workers } \\
\hline & $r$-value & $P$-value & $r$-value & $P$-value \\
\hline $\begin{array}{l}\text { Red blood cells } \\
\quad \text { (million cells } / \mu l)\end{array}$ & -0.061 & 0.672 & 0.093 & 0.539 \\
\hline $\begin{array}{l}\text { Hemoglobin } \\
\quad(\mathrm{gram} / \mathrm{dl})\end{array}$ & -0.013 & 0.931 & -0.152 & 0.293 \\
\hline Hematocrit value (\%) & -0.087 & 0.550 & -0.123 & 0.395 \\
\hline $\begin{array}{l}\text { Mean corpuscular volume (MCV) } \\
\text { FL }\end{array}$ & -0.084 & 0.562 & 0.178 & 0.215 \\
\hline $\begin{array}{l}\text { Mean corpuscular hemoglobin(MCH) } \\
\text { pg/cell }\end{array}$ & 0.062 & 0.671 & 0.088 & 0.543 \\
\hline $\begin{array}{l}\text { Mean corpuscular hemoglobin } \\
\text { concentration (MCHC) } \\
\text { gram/dl }\end{array}$ & 0.232 & 0.106 & -0.076 & 0.599 \\
\hline $\begin{array}{l}\text { Platelet count } \\
\text { (billion/l) }\end{array}$ & 0.163 & 0.257 & -0.004 & 0.980 \\
\hline White Blood Cell/ $/$ l & 0.260 & 0.069 & 0.218 & 0.129 \\
\hline Neutrophils (\%) & -0.078 & 0.589 & 0.193 & 0.179 \\
\hline Lymphocytes(\%) & -0.078 & 0.589 & -0.256 & 0.073 \\
\hline Monocytes (\%) & 0.081 & 0.576 & 0.116 & 0.453 \\
\hline Eosinophils(\%) & -0.190 & 0.187 & -0.057 & 0.694 \\
\hline Basophils (\%) & -0.121 & 0.403 & -0.101 & 0.486 \\
\hline $\begin{array}{l}\text { Malondialdehyde } \\
\mathrm{nmol} / \mathrm{ml}\end{array}$ & -0.101 & 0.485 & 0.047 & 0.748 \\
\hline Total Anti-Oxidant mM/L & -0.077 & 0.594 & -0.055 & 0.705 \\
\hline $\begin{array}{l}\text { Human Caspase-3 } \\
\mathrm{Pg} / \mathrm{ml}\end{array}$ & -0.031 & 0.830 & 0.106 & 0.463 \\
\hline $\begin{array}{l}\text { Human } \mathrm{BCl} 2 \\
\mathrm{ng} / \mathrm{ml}\end{array}$ & 0.012 & 0.935 & -0.149 & 0.303 \\
\hline $\begin{array}{l}\text { Human } 8 \mathrm{OHdG} \\
\mathrm{ng} / \mathrm{ml}\end{array}$ & 0.134 & 0.624 & -0.034 & 0.817 \\
\hline
\end{tabular}

The effect of smoking on biochemical markers in occupationally exposed workers showed no significant difference when compared with controls (Table 7).

On the other hand, significant negative correlations between duration of occupational exposure of workers to paint hazards and red blood cells $(r=-0.281, p<0.05)$, white blood cells $(r=-0.305, \mathrm{p}<0.05)$, lymphocytes $(r=$ -0.316, $\mathrm{p}<0.05)$ and monocytes $(r=-0.304, p<0.01)$ were observed (Table 8 and Figs. 1, 2, 3 and 4).

Table 9 and Figs. 5 and 6 showed significant positive correlations between duration of work and human 8-OHdG and highly significant negative correlations between duration of work and total antioxidants.

Table 10 represents correlations between (red blood cells \& platelets parameters) and biochemical markers under the effect of occupational exposure to paint hazards. The results showed highly significant negative correlation between RBC count and increased apoptosis assayed by increase in the mean values of caspase-3 $(r=-0.578$, $p \leq 0.001)$ and with increased DNA damage represented by increase in the mean values of human 8-OHdG ( $r=$ $-0.574, p \leq 0.001)$. However, RBC counts showed significant positive correlation with anti-apoptotic marker, human $\operatorname{Bcl}-2(r=0.243, p<0.05)$.

$\mathrm{MCHC}$ was high significantly negatively correlated with the increase of oxidative stress assayed by malondialdehyde $(r=-0.339, p<0.05)$. The results also showed the significant positive correlation between platelet count and total anti-oxidant capacity $(r=0.320, p<0.05)$.

On the other hand, a highly significant negative correlation between decrease in the total number of WBCs and increased oxidative stress represented by increase in the mean values of malondialdehyde $(r=-0.504, p \leq 0.001)$ was observed, with increased apoptosis represented by increase in the mean values of caspase-3 $(r=-0.574, p \leq 0.001)$ and with increased DNA damage represented by increase in the mean values of human 8 -OHdG $(r=-0.584, p \leq 0.001)$. However, total WBC count showed highly significant positive correlation with the decrease in total anti-oxidant 
Table 7 Effect of smoking on the biochemical markers in painters

\begin{tabular}{llll}
\hline Bioindicies & & $\begin{array}{l}\text { Smokers } \\
(N=22)\end{array}$ & $\begin{array}{l}\text { Non-smokers } \\
(N=28)\end{array}$ \\
\hline Malondialdehyde & Mean \pm SE & $6.50 \pm 1.29$ & $6.56 \pm 1.53$ \\
nmol/ml & Median (Range) & $6.60(3.90-8.50)$ & $7.15(4.20-9.10)$ \\
Total Anti-Oxidant & Mean \pm SE & $0.18 \pm 0.10$ & $0.15 \pm 0.07$ \\
mM/L & Median (Range) & $0.14(0.06-0.50)$ & $0.15(0.01-0.26)$ \\
Human Caspase-3 & Mean \pm SE & $0.68 \pm 0.42$ & $0.65 \pm 0.44$ \\
Pg/ml & Median (Range) & $0.52(0.24-1.65)$ & $0.50(0.22-1.48)$ \\
Human Bcl2 & Mean \pm SE & $0.12 \pm 0.55$ & $0.40 \pm 1.00$ \\
ng/ml & Median (Range) & $0.00(0.00-2.60)$ & $0.00(0.00-3.10)$ \\
Human 8 OHdG & Mean \pm SE & $0.61 \pm 1.57$ & $0.60 \pm 1.50$ \\
ng/ml & Median (Range) & $0.00(0.00-4.60)$ & $0.00(0.00-4.80)$ \\
\hline
\end{tabular}

N.B: The differences between the 2 groups were non - significant

capacity $(r=0.465, p \leq 0.001)$ and significant positive correlation with decrease in anti-apoptotic marker (human Bcl-2) $(\mathrm{r}=0.243, P<0.05)$ (Table 11$)$.

Monocytes percentage was significantly negatively correlated with the increase in the mean level of caspase-3 $(r=-0.302, \mathrm{p}<0.05)$. However, basophil percentage was significantly positively correlated with increased in DNA damage represented by increase in the mean values of human 8-OHdG $(r=0.308, p<0.05)$.

\section{Discussion}

Paint workers are exposed to a various variety of harmful chemicals present in paint products such as solvents (aromatic hydrocarbons: Benzene, Toluene, and Xylene) (Roma-Torres et al. 2006). Also, paints contain pigments such as lead, cadmium, arsenic and chromium (Awodele

Table 8 Correlation between duration of exposure of workers (years) to paint hazards and hematological parameters

\begin{tabular}{|c|c|c|}
\hline \multirow[t]{2}{*}{ Hematological parameters } & \multicolumn{2}{|c|}{ Duration of work } \\
\hline & $r$-value & $P$-value \\
\hline Red blood cells (million cells/ul) & -0.332 & $0.021^{*}$ \\
\hline Hemoglobin (gram/dl) & -0.073 & 0.613 \\
\hline Hematocrit value (\%) & -0.148 & 0.305 \\
\hline Mean corpuscular volume (MCV) FL & -0.097 & 0.502 \\
\hline Mean corpuscular hemoglobin(MCH)pg/cell & -0.154 & 0.285 \\
\hline $\begin{array}{l}\text { Mean corpuscular hemoglobin concentration } \\
\text { (MCHC) gram/dl }\end{array}$ & -0.103 & 0.477 \\
\hline Platelet count(billion/l) & 0.120 & 0.405 \\
\hline White blood cells $\times 103 / \mu l$ & -0.607 & $0.001^{* * *}$ \\
\hline Neutrophils (\%) & -0.029 & 0.839 \\
\hline Lymphocytes(\%) & -0.316 & $0.025^{*}$ \\
\hline Monocytes (\%) & -0.404 & $0.004^{* *}$ \\
\hline Eosinophils(\%) & 0.055 & 0.706 \\
\hline Basophilis(\%) & 0.026 & 0.860 \\
\hline
\end{tabular}

et al. 2014). Besides, Titanium dioxide and silver are nanoparticles used as paint additives (Smulders et al. 2014). All these constituents were reported by many studies to have adverse effects on neurobehavioral, blood, kidney, liver, cardiac, respiratory functions, spleen and many body systems (Chen et al. 2001; Ridgway et al. 2003; Agin et al. 2016). Toxic effects of these materials on the DNA and blood can contribute to their carcinogenicity (Scélo et al. 2009).

The influences of age, sex, and smoking on DNA damage are well-known problems in occupation (Faust et al. 2004; Madhavi et al. 2008). However, in this study these factors were excluded; in both groups, the mean age was similar, all persons were men, and there were no significant changes between workers group compared to control group regarding smoking habits. Mean values for biochemical indices were not different in smokers and non-smokers among workers. Similarly, Silva et al. (1996) concluded that smoking habits do not represent a significant factor of chromosome aberrations found in their occupational monitoring of car painters.

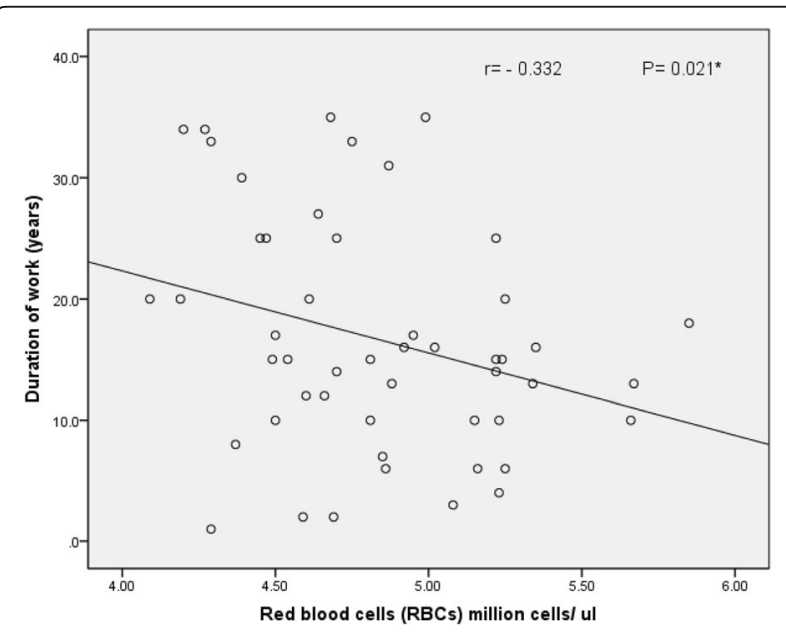

Fig. 1 Correlation between duration of work and RBCs 


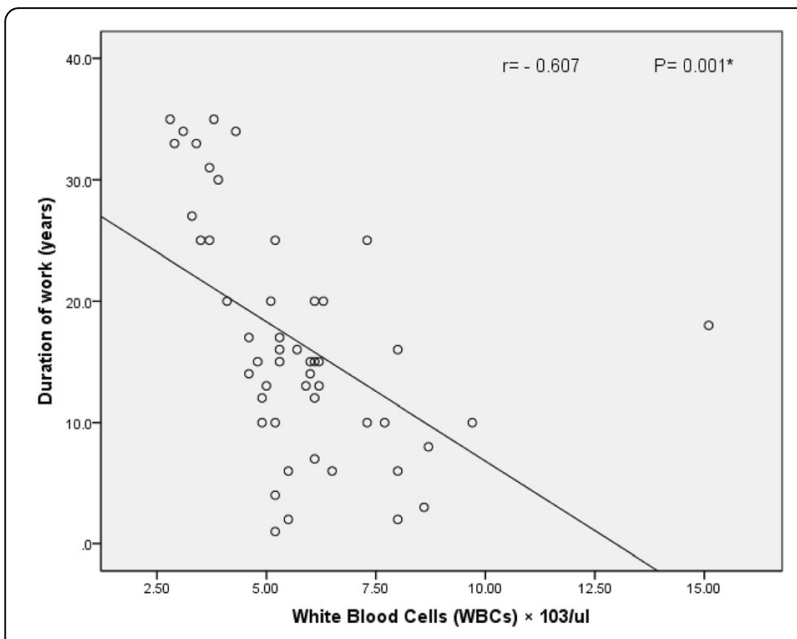

Fig. 2 Correlation between duration of work and WBCs

In the current work workers presented some manifestations including arthralgia (50\%), pallor (40\%) easy fatigability (32\%), dyspnea (20\%) and numbness of the extremities (10\%) which were absent among the control group.

The study of Karrari et al. (2012) that reported that workers occupationally exposed to paints showed anemia, fatigue and dyspnea which may be attributed to the presence of lead in paint materials, is in agreement with these findings. Coinciding with results of this study, Agarwl et al. (2016) noted presence of abdominal pain, numbness of extremities in painters using lacquer tinning for removing household agents as it contains various aromatic hydrocarbons as naphthalene.

In the present study, there was a statistically significant decrease in the hemoglobin level, the red cell count, the hematocrit value, mean corpuscular hemoglobin concentration, and non-significant decrease in platelet count in painters when compared with control group. In addition

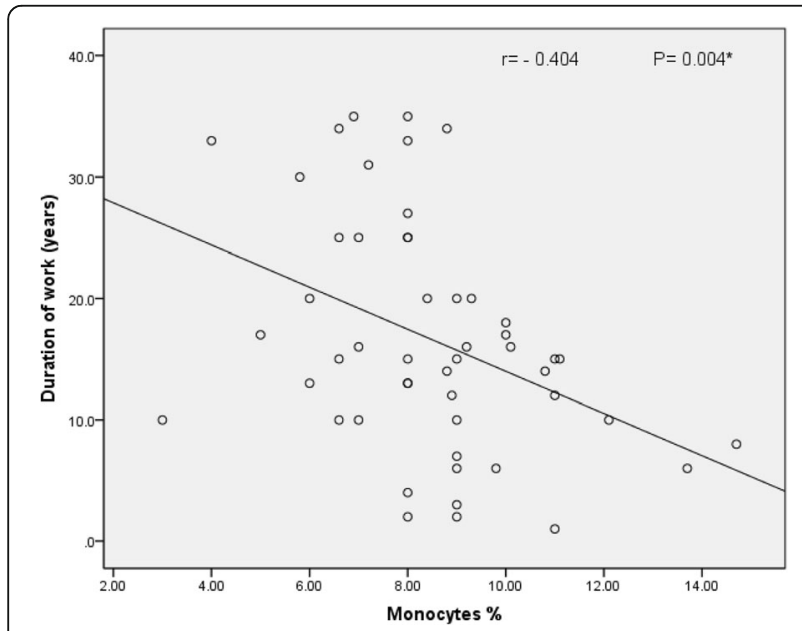

Fig. 3 Correlation between duration of work and monocytes

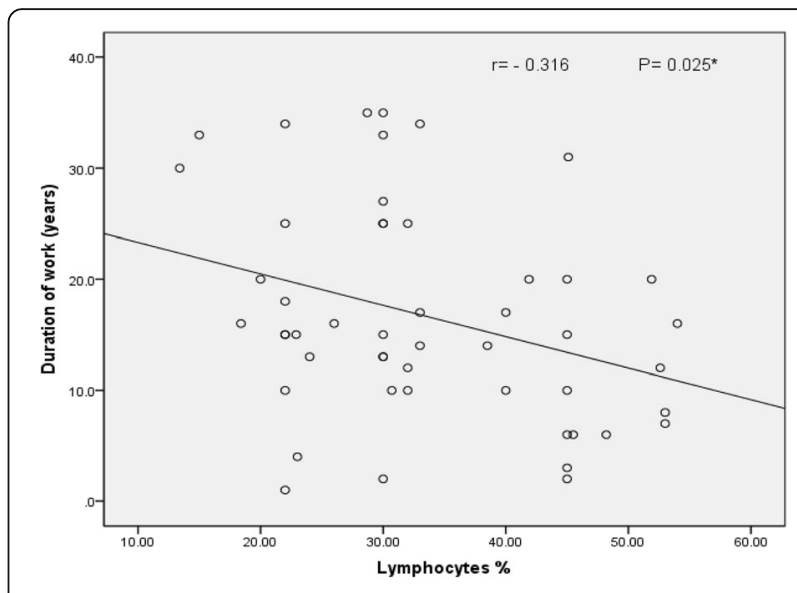

Fig. 4 Correlation between duration of work and lymphocytes

there was a statistically significant decrease in the total white blood cell compared to the control group. This may attributed to depression of the bone marrow (Wang et al. 2012). There was also an increase basophils in painters compared to controls.

The results of the study of Maity (2013) on mice treated with solvents showed significant decrease in the blood haemoglobin level and erythrocyte count. Measurements of haematological parameters may be a tool for early detection of cellular changes in the blood caused by exposure to solvents, before the appearance of clinical symptoms. In agreement with the results of the present work was the study of Gadwal et al. (2014)who noticed presence of a statistically significant decrease in RBCs, hemoglobin, neutrophils, platelets and total leucocytic count in painters.

In the current study, an increase in eosinophils, lymphocytes and basophils was also noted in painters as compared to non-painters. In agreement with our study, Ibrahim et al. (2012) reported that many solvents in paint materials may be responsible for decrease in RBCs, WBCs, and platelets in exposed painters as compared with the non-exposed controls. They stated that organic solvents

Table 9 Correlation between duration of exposure of workers (years) to paint hazards and different biochemical markers

\begin{tabular}{lll}
\hline $\begin{array}{l}\text { Biochemical } \\
\text { parameters }\end{array}$ & \multicolumn{2}{l}{ Duration of work } \\
\cline { 2 - 3 } & $r$-value & $P$-value \\
\hline Malondialdehyde & 0.165 & 0.253 \\
$\begin{array}{l}\text { Total Anti-Oxidant } \\
\text { mM/L }\end{array}$ & -0.390 & $0.005^{* *}$ \\
$\begin{array}{l}\text { Caspase-3 } \\
\text { Pg/ml }\end{array}$ & 0.079 \\
$\begin{array}{l}\text { Human Bcl-2 } \\
\text { ng/ml }\end{array}$ & 0.251 & 0.973 \\
$\begin{array}{l}\text { Human(8-OHdG) } \\
\text { ng/ml }\end{array}$ & -0.005 & \\
${ }^{* *} P$-value $\leq 0.01$ high significant, ${ }^{* * *} P$-value $\leq 0.001$ highly significant &
\end{tabular}




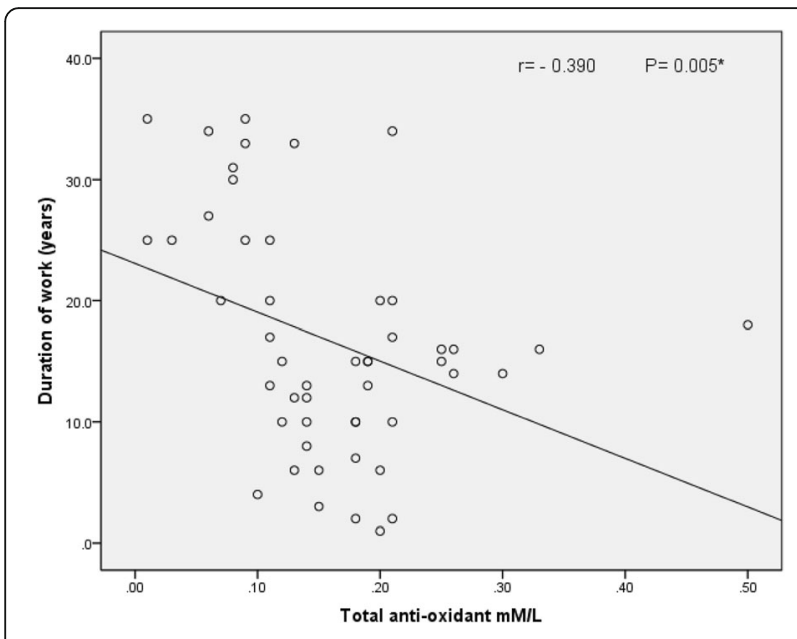

Fig. 5 Correlation between duration of work and total anti-oxidant capacity

in paints may impair the immune system and could be considered as immune suppressors.

Leucopenia recorded in paint workers in this study may be explained by the fact that the essential function of WBCs is to provide primary defense or to provide immunologic response against foreign chemical agents introduced into the body (Uboh et al. 2009). Increased reactive lymphocytes were large sized due to antigenic stimulation (Kalele et al. 2016). This was in agreement with the findings of Eracal et al. (2000) they found in their study on painters an increased number of reactive lymphocytes. Elevated basophilic count noticed among painters may be due to allergic reactions secondary to occupational exposure to irritant paint chemicals, basophils are important as mediators in late-phase allergic reactions, this plays important role in chronic inflammation (Gibbs 2005; El-Gharabawy et al. 2013).

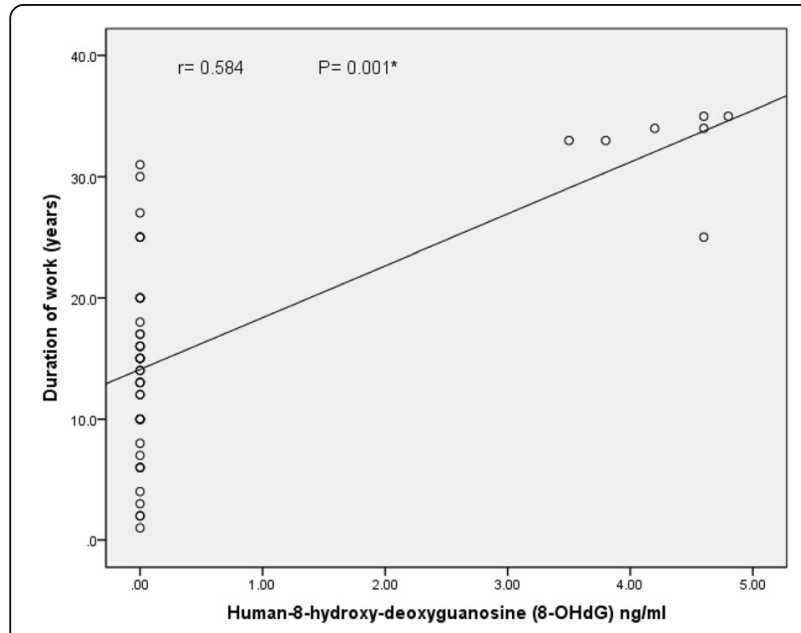

Fig. 6 Correlation between duration of work and Human $(8-\mathrm{OHdG})$
Reactive oxygen species induced lipid peroxidation which is an oxidative process associated with membrane lipid destruction. MDA is formed as its end product. Anti-oxidant enzymes are defense system against oxidative stress (Barrera 2012; Conterato et al. 2013).

Normally there is a balance between free radicals and antioxidants, as well as apoptotic and anti-apoptotic markers in body cells. This balance is necessary for proper physiological function (Lobo et al. 2010; Rahman 2007). If free radicals exceed the body's ability to neutralise them, a condition known as oxidative stress occurs. On the other hand antioxidants decrease cell damage by direct scavenging of ROS (Li et al. 2015).

In the present study, there was a significant increase in MDA activity that occurred in workers exposed to paint materials. In agreement with our results the study of Moro et al. (2010) and Conterato et al. (2013) reported an increased MDA level in painters occupationally exposed to paint thinners.

In our study there was statistically significant decrease in total antioxidant capacity in painters compared to control group. Antioxidant capacity may give more biological information than assay of individual components, as it includes the cumulative effect of all antioxidants present in plasma and body fluids (Huang et al. 2005).

Caspase-3 plays a major role in the execution-phase of cell apoptosis (Khan 2010). The Bcl-2 is an anti-apoptotic protein that prevents apoptosis by controlling caspases activation or by guarding mitochondrial membrane integrity (Andreu-Fernández et al. 2017).

Rana (2008) mentioned that the heavy metals and organic solvents in paints induced apoptosis by activation of mitochondrial apoptogenic proteins, then apoptotic signal proceeds and cell death occurs (Roset et al. 2007).

The current study showed increase apoptosis in painters compared to control group as indicated by increased levels of caspase- 3 and decrease in Bcl 2 levels in serum.

These findings were in agreement with El-Nabi kamel and Shehata (2008) who revealed increase in apoptotic marker caspase- 3 and oxidative stress after exposure of rats to toluene. Also, coinciding with the results of Tousson et al. (2011) who mentioned that exposure of rabbits to lead caused a significant decrease in the anti-apoptotic $\mathrm{Bcl}-2$ proteins. Xenobiotics initiate apoptosis signaling pathways (Ray et al. 2012). These pathways lead to activation of caspases result in formation of apoptotic bodies and DNA fragmentation (Elmore 2007).

DNA bases are damaged by exposure to environmental oxidants such as painting materials. The resultant damage may be a significant source of mutations that lead to cancer and other human diseases (Lobo et al. 2010). Measurement of (8-OHdG) is a highly sensitive assay for oxygen free radical damage to DNA (Canakci et al. 2009; Valavanidis et al. 2009). This biomarker has 
Table 10 Correlation between RBC parameters and biochemical parameters in workers exposed to paints

\begin{tabular}{|c|c|c|c|c|c|c|}
\hline Parameters & & MDA & T. Anti-Oxidant & Human Caspase-3 & Human Bcl-2 & Human $8 \mathrm{OHdG}$ \\
\hline \multirow{2}{*}{$\begin{array}{l}\text { Red blood cells } \\
\text { million cells } / \mu l\end{array}$} & $r$-value & -0.075 & 0.046 & -0.578 & 0.243 & -0.574 \\
\hline & P-value & 0.603 & 0.754 & $0.001^{* * *}$ & $0.040^{*}$ & $0.001^{* * *}$ \\
\hline \multirow[t]{2}{*}{ Hemoglobin g/dl } & r-value & -0.090 & 0.176 & -0.007 & 0.193 & -0.115 \\
\hline & P-value & 0.534 & 0.222 & 0.960 & 0.179 & 0.426 \\
\hline \multirow[t]{2}{*}{ Hematocrit\% } & r-value & -0.226 & 0.041 & -0.174 & 0.198 & -0.036 \\
\hline & P-value & 0.115 & 0.779 & 0.227 & 0.168 & 0.801 \\
\hline \multirow{2}{*}{$\begin{array}{r}\mathrm{MCV} \\
\mathrm{Fl}\end{array}$} & r-value & -0.128 & 0.002 & -0.018 & 0.153 & -0.040 \\
\hline & P-value & 0.377 & 0.991 & 0.902 & 0.287 & 0.783 \\
\hline \multirow{2}{*}{$\begin{array}{l}\mathrm{MCH} \\
\mathrm{pg} / \mathrm{cell}\end{array}$} & r-value & -0.065 & 0.105 & -0.064 & 0.084 & -0.086 \\
\hline & P-value & 0.652 & 0.467 & 0.660 & 0.561 & 0.552 \\
\hline \multirow{2}{*}{$\begin{array}{l}\mathrm{MCHC} \\
\mathrm{g} / \mathrm{dL}\end{array}$} & r-value & -0.339 & 0.201 & -0.094 & 0.084 & -0.006 \\
\hline & P-value & $0.016^{* *}$ & 0.162 & 0.515 & 0.561 & 0.968 \\
\hline \multirow{2}{*}{$\begin{array}{l}\text { Platelet count } \\
\text { billion/L }\end{array}$} & r-value & -0.220 & 0.320 & -0.110 & 0.124 & -0.061 \\
\hline & P-value & 0.125 & $0.024^{*}$ & 0.448 & 0.392 & 0.673 \\
\hline
\end{tabular}

$\%=$ percentage, ${ }^{*} P$-value $\leq 0.05$ significant, ${ }^{* *} P$-value $\leq 0.01$ high significant, ${ }^{* * *} P$-value $\leq 0.001$ highly significant

been used to estimate the DNA damage in humans after exposure to cancer-causing agents, such as heavy metals, and polycyclic aromatic hydrocarbons (Bulat et al. 2008).

In the present work, a significant increase in DNA damage was evaluated by (8-OHdG) observed in workers exposed to paints compared to control group. This is in agreement with Liub et al. (2009) who found significantly higher serum 8-OHdG levels in exposed workers compared to the control group. Also, in agreement with the study of Chang et al. (2011) of 8-OHdG levels in urinary samples, they found to be higher in painters than the control group.

In the present study, oxidative stress and apoptotic effect of xenobiotics on RBCs showed statistically significant negative correlation with caspase- 3 and human 8-OHdG and showed a significant positive correlation with Bcl-2. MCHC showed significant negative correlation with MDA. The platelets showed significant positive correlation with total antioxidant.

The WBCs showed significant negative correlation with MDA, caspase-3 and significant positive correlation with total antioxidant and Bcl-2. The monocytes showed significant negative correlation with caspase-3.

The effect of exposure of paint chemicals in the present study on blood cells showed significant negative correlation between human 8-OHdG and WBCs and significant positive correlation with basophilis.

In agreement with Keating et al. (2011), it is known that apoptosis has adverse effects on the hematological system.

Table 11 Correlation between total and differential white blood cell count and biochemical parameters in workers exposed to paints

\begin{tabular}{|c|c|c|c|c|c|c|}
\hline Parameters & & MDA & T. Anti-Oxidant & $\begin{array}{l}\text { Human } \\
\text { Caspase-3 }\end{array}$ & $\begin{array}{l}\text { Human } \\
\mathrm{Bcl}-2\end{array}$ & $\begin{array}{l}\text { Human } 8 \\
\text { OHdG }\end{array}$ \\
\hline \multirow{2}{*}{$\begin{array}{l}\text { White Blood Cells } \\
\times 103 / \mu l\end{array}$} & r-value & -0.504 & 0.465 & -0.574 & 0.243 & -0.584 \\
\hline & P-value & $0.001^{* * *}$ & $0.001^{* * *}$ & $0.001^{* * *}$ & $0.039^{*}$ & $0.001^{* * *}$ \\
\hline \multirow[t]{2}{*}{ Neutrophils\% } & r-value & -0.153 & -0.038 & -0.076 & 0.169 & -0.206 \\
\hline & P-value & 0.290 & 0.793 & 0.600 & 0.240 & 0.152 \\
\hline \multirow[t]{2}{*}{ Lymphocytes\% } & r-value & 0.138 & -0.072 & -0.115 & 0.139 & 0.258 \\
\hline & P-value & 0.339 & 0.620 & 0.425 & 0.335 & 0.071 \\
\hline \multirow[t]{2}{*}{ Monocytes\% } & r-value & 0.276 & 0.025 & -0.302 & 0.075 & -0.082 \\
\hline & P-value & 0.052 & 0.865 & $0.033^{*}$ & 0.606 & 0.573 \\
\hline \multirow[t]{2}{*}{ Eosinophils\% } & r-value & 0.145 & 0.056 & -0.171 & -0.035 & -0.050 \\
\hline & P-value & 0.316 & 0.699 & 0.235 & 0.807 & 0.728 \\
\hline \multirow[t]{2}{*}{ Basophils\% } & r-value & 0.027 & -0.146 & -0.200 & 0.050 & 0.308 \\
\hline & P-value & 0.851 & 0.313 & 0.164 & 0.728 & $0.030^{*}$ \\
\hline
\end{tabular}

$\%=$ percentage, ${ }^{*} P$-value $\leq 0.05$ significant, ${ }^{* * *} P$-value $\leq 0.001$ highly significant 
This could explain the aforementioned hematological markers abnormalities (Yedjou et al. 2010). In the present study there was a positive correlation between decrease in hemoglobin concentration, RBC numbers, caspase- 3 and decrease in human 8-OHdG.

In agreement, the findings of Aksoy et al. (2006) who mentioned that DNA damage in painters impairs the induction cells of the hematopoietic system including spleen, lymphatic tissues and bone marrow in mice caused by paint thinner materials was evident by chromosomal aberrations; DNA adduct formation, micronucleus formation and increase apoptosis.

In the present work, a decrease in RBCs, WBCs, lymphocytes and monocytes in whole blood samples were found in workers exposed to paints for a long period. An increase in DNA damages (8-OHdG) and decrease in antioxidant capacity were also observed with the increase in duration of exposure to paints. The increase in DNA damage (8-OHdG) in workers was observed in those exposed to paint hazards for more than 20 years of duration of work (Fig. 6).

In agreement with our results Cassini et al. (2011), observed a positive correlation in DNA damages assayed by comet assay in workers exposed to paints with the daily exposure time.

\section{Conclusion}

This study performed on paint workers in Assiut governorate showed evidence of hematotoxicity and genotoxicity. This was demonstrated by clinical examination and biochemical assays. The oxidative stress and apoptosis were found to play a major role on different hematological parameters as well as DNA damage. Periodic medical examination and laboratory investigations are mandatory to discover early hazardous health effects especially among chronic exposure to paints. Paint workers should use protective devices as gloves and masks during their routine work.

\section{Acknowledgements}

Not applicable.

\section{Funding}

The research has been funded by Assiut Faculty of Medicine Research Grant Office.

\section{Availability of data and materials}

The data used and/or analyzed in this study are available from the corresponding author on reasonable request.

\section{Authors' contributions}

NAM: Protocol development, manuscript writing. KAA: Protocol development, manuscript editing. NG: Protocol development, manuscript editing. ME: Data management, biochemical analysis, manuscript editing. ES: Data collection, data management, manuscript writing. All authors read and approved the final manuscript.

\section{Ethics approval and consent to participate}

This work had the approval from Research and Ethical committee of Faculty of Medicine, Assiut University. Informed consent was taken from all individuals who participated in the study. Confidentiality of the data was guaranteed.

\section{Consent for publication}

Not applicable.

\section{Competing interests}

The authors declare that they have no competing interests.

\section{Publisher's Note}

Springer Nature remains neutral with regard to jurisdictional claims in published maps and institutional affiliations.

\section{Author details}

${ }^{1}$ Department of Forensic medicine and Clinical toxicology, Assiut University Faculty of Medicine, Asyut, Egypt. ${ }^{2}$ department of Medical Biochemistry, Assiut University Faculty of Medicine, Asyut, Egypt.

Received: 6 June 2017 Accepted: 22 November 2017

Published online: 23 January 2018

\section{References}

Agarwal C, Mohanpuria A, Buxi G, Kumar V (2016) Coincidental finding of Beta Thalassaemia minor in a patient of lacquer thinner poisoning presenting as Methaemoglobinemia. J Clin Diagn Res 10(11):ED08-ED09

Agin K, Hassanian-Moghaddam H, Shadnia S, Rahimi HR (2016) Characteristic manifestations of acute paint thinner-intoxicated children. Environ Toxicol Pharmacol 45(15):9

Aksoy H, Yilmaz S, Celik M, Yüzbaşioglu D, Unal F (2006) J Appl Toxicol 26(1):10-15 Andreu-Fernández V, Sancho M, Genovés A, Lucendo E, Todt F, Lauterwasser J (2017) Baxtransmembrane domain interacts with prosurvival $\mathrm{BCl}-2$ proteins in biological membranes. Proc Natl Acad Sci U S A 114(2):310-315

Anetor II (2010) Industrialization and the increasing risk of genome instability in developing countries: nutrigenomics as a promising antidote. Afr J Med Med Sci 39(Suppl):7-20

Awodele O, Popoola TD, Ogbudu BS, Akinyede A, Coker HA, Akintonwa A (2014) Occupational hazards and safety measures amongst the paint factory workers in lagos, Nigeria. Saf Health Work 5(2):106-111

Barrera G (2012) Oxidative stress and lipid peroxidation products in cancer progression and therapy. ISRN Oncol 2012:137289

Bulat P, Potkonjak B, Dujić I (2008) Lipid peroxidation and antioxidative enzyme activity in erythrocytes of workers occupationally exposed to aluminum. Arh Hig Rada Toxicol 59(2):81-87

Canakci CF, Canakci V, Tatar A, Eltas A, Sezer U, Cicek Y (2009) Increased salivary level of 8-hydroxydeoxyguanosine is a marker of premature oxidative mitochondrial DNA damage in gingival tissue of patients with periodontitis. Arch Immunol Ther Exp 57(3):205-211

Cassini C, Calloni C, Bortolini G, Garcia SC, Dornelles MA, Henriques JA (2011) Int J Occup Med Environ Health 24(3):308-319

Chang FK, Mao IF, Chen ML, Cheng SF (2011) Urinary 8-hydroxydeoxyguanosine as a biomarker of oxidative DNA damage in workers exposed to ethylbenzene. Ann Occup Hyg 55(5):519-525

Chen R, Dick F, Seaton A (1999) Health effects of solvent exposure among dockyard painters: mortality and neuropsychological symptoms. Occup Environ Med 56(6):383-387

Chen R, Dick F, Semple S, Seaton A, Walker LG (2001) Exposure to organic solvents and personality. Occup Environ Med 58(1):14-18

Conterato GM, Bulcão RP, Sobieski R, Moro AM, Charão MF, de Freitas FA (2013) Blood thioredoxinreductase activity, oxidative stress and hematological parameters in painters and battery workers: relationship with lead and cadmium levels in blood. J Appl Toxicol 33(2):142-150

de Oliveira HM, Dagostim GP, da Silva AM, Tavares P, da Rosa LA, de Andrade VM (2011) Occupational risk assessment of paint industry workers. Indian J Occup Environ Med 15(2):52-58

El-Gharabawy RM, El-Maddah El, Oreby MM, Salem HS, Ramadan MO (2013) Immunotoxicity and pulmonary toxicity induced by paints in Egyptian painters. J Immunotoxicol 10(3):270-278

Elmore S (2007) Apoptosis: a review of programmed cell death. Toxicol Pathol 35(4):495-516 
El-NabiKamel MA, Shehata M (2008) Effect of toluene exposure on the antioxidant status and apoptotic pathway in organs of the rat. $\mathrm{Br} \mathrm{J}$ Biomed Sci 65(2):75-79

Ercal N, Neal R, Treeratphan P, Lutz PM, Hammond TC, Dennery PA (2000) A role for oxidative stress suppressing serum immunoglobulin levels in lead exposed fisher rats. Arch Environ Contam Toxicol 39(2):251-256

Faust F, Kassie F, Knasmuller S, Boedecker RH, Mann M, Mersch-Sundermann V (2004) The use of the alkaline comet assay with lymphocytes in human biomonitoring studies. Mutat Res 566:209-229

Gadwal R, Herur A, Chinagudi S, Shashikala GV, Patil S, Ankad R (2014) Hematological profile of painters : a case - control study. RRJMHS 3(2):128-130

Gibbs BF (2005) Human basophils as effectors and immunomodulators of allergic inflammation and innate immunity. Clin Exp Med 5:43-49

Glantz LA, Gilmore JH, Lieberman JA, Jarskog LF (2006) Apoptotic mechanisms and the synaptic pathology of schizophrenia. Schizophr Res 1 81(1):47-63

Hoeijmakers JH (2009) DNA damage, aging, and cancer. N Engl J Med 8 361(15): $1475-1485$

Huang D, Ou B, Prior RL (2005) The chemistry behind antioxidant capacity assays. J Agric Food Chem 53(6):1841-1856

Hyun J, Grova M, Nejadnik H, Lo D, Morrison S, Montoro D (2013) Enhancing in vivo survival of adipose-derived stromal cells through Bcl-2 overexpression using a minicircle vector. Stem Cells Transl Med 2(9):690-702

Ibrahim KS, Amer NM, El-Dossuky EA, Emara AM, El-Fattah AE, Shahy EM (2012) Hematological effects of benzene exposure with emphasis on muconic acid as a biomarker in exposed workers. Toxicol Ind Health 28:1-10

Kalele KP, Patil KP, Nayyar AS, Sasane RS (2016) Atypical lymphocytes and cellular cannibalism: a phenomenon, first of its kind to be discovered in chronic Periapical lesions. J Clin Diagn Res 10(4):ZC01-ZCO4

Kamal A, Malik RN (2012) Hematological evidence of occupational exposure to chemicals and other factors among auto-repair Workers in Rawalpindi, Pakistan. Osong Public Health Res Perspect 3(4):229-238

Karrari P, Mehrpour O, Abdollahi M (2012) A systematic review on status of lead pollution and toxicity in Iran; guidance for preventive measures. Daru 20(1):2

Kaukiainen A, Vehmas T, Rantala K, Nurminen M, Martikainen R, Taskinen H (2004) Results of common laboratory tests in solvent-exposed workers. Int Arch Occup Environ Health 77(1):39-46

Keating FK, Butenas S, Fung MK, Schneider DJ (2011) Platelet-white blood cell (WBC) interaction, WBC apoptosis, and procoagulant activity in stored red blood cells. Transfusion 51(5):1086-1095

Khan AA (2010) Intracellular mechanisms of apoptosis. J Biol Sci 10(4):291-305

Koracevic D, Koracevic G, Djordjevic V, Andrejevic S, Cosic V (2001) Method for the measurement of antioxidant activity in human fluids. J Clin Pathol 54(5):356-361

Li S, Tan HY, Wang N, Zhang ZJ, Lao L, Wong CW (2015) The role of oxidative stress and antioxidants in liver diseases. Int J Mol Sci 16(11):26087-26124

Liub HH, Ming HL, Po CL, Chia IC, Hsiu LC (2009) Health risk assessment by measuring plasma malondialdehyde (MDA), urinary 8hydroxydeoxyguanosine (8-OH-dG) and DNA strand breakage following metal exposure in foundry workers. J Hazard Mat 170(2-3):699-704

Lobo V, Patil A, Phatak A, Chandra N (2010) Free radicals, antioxidants and functional foods: impact on human health. Pharmacogn Rev 4(8):118-126

Madhavi D, Devi KR, Sowjanya BL (2008) Increased frequency of chromosomal aberrations in industrial painters exposed to lead-based paints. J Environ Pathol Toxicol Oncol 27:53-59

Maity D (2013) A study of Haematotoxicity of lead on Swiss mice. Int J Adv Sci Tech Res 3(3):84-90

Moro AM, Charão M, Brucker N, Bulcão R, Freitas F, Guerreiro G (2010) Effects of low-level exposure to xenobiotics present in paints on oxidative stress in workers. Sci Total Environ 408(20):4461-4467

Ohkawa H, Ohishi N, Yagi K (1979) Assay for lipid peroxides in animal tissues by thiobarbituric acid reaction. Anal Biochem 95(2):351-358

Park J, Lee CG, Ryu SY (2006) Factors related to the prevalence of respiratory symptoms in workers in a petrochemical complex. J Occup Health 48(3):216-222

Rabinowitz PM, Galusha D, Slade MD, Dixon-Ernst C, O'Neill A, Fiellin M (2008) Organic solvent exposure and hearing loss in a cohort of aluminium workers Occup Environ Med 65(4):230-235

Rahman K (2007) Studies on free radicals, antioxidants, and co-factors. Clin Interv Aging 2(2):219-236

Rana SVS (2008) Metals and apoptosis: recent developments. J Trace Elem Med Bio 22:262-284

Ray PD, Huang BW, Tsuji Y (2012) Reactive oxygen species (ROS) homeostasis and redox regulation in cellular signaling. Cell Signal 24(5):981-990
Ridgway P, Nixon TE, Leach JP (2003) Occupational exposure to organic solvents and long-term nervous system damage detectable by brain imaging neurophysiology or histopathology. Food Chem Toxicol 41(2):153-187

Roma-Torres J, Teixeira JP, Silva S, Laffon B, Cunha LM, Méndez J (2006) Evaluation of genotoxicity in a group of workers from a petroleum refinery aromatics plant. Mutat Res 604:19-27

Roset R, Ortet L, Gil-Gomez G (2007) Role of Bcl-2 family members on apoptosis what we have learned from knock-out mice. Front Biosci 12:4722-4730

Satoh K (1978) Serum lipid peroxide in cerebrovascular disorders determined by a new colorimetric method. Clin Chim Acta 15 90(1):37-43

Scélo G, Metayer C, Zhang L, Wiemels JL, Aldrich MC, Selvin S (2009) Household exposure to paint and petroleum solvents, chromosomal translocations, and the risk of childhood leukemia. Environ Health Perspect 117(1):133-139

Silva JM, Santos-Mello R (1996) Chromosomal aberrations in lymphocytes from car painters. Mutat Res 368:21-25

Smulders S, Luyts K, Brabants G, Landuyt KV, Kirschhock C, Smolders E (2014) Toxicity of nanoparticles embedded in paints compared with pristine nanoparticles in mice. Toxicol Sci 141(1):132-140

Sova H, Jukkola-Vuorinen A, Puistola U, Kauppila S, Karihtala P (2010) 8Hydroxydeoxyguanosine: a new potential independent prognostic factor in breast cancer. Br J Cancer 16 102(6):1018-1023

Tousson E, Rafat BM, Hessien M, El Barbary AA, Sami A (2011) P53 and Bcl2 apoptosis proteins in meso-2,3-dimercaptosuccinic acid treated leadintoxicated rabbits. Toxicol Ind Health 27(3):271-278

Uboh FE, Akpanabiatu Ml, Alozie Y, Ebong PE, Ndem Jl, Edent EE (2009) Effect of vitamin a on weight-loss and Haematotoxicity associated with gasoline vapors exposure in male rats. Int J Pharmacol 5(3):215-221

Valavanidis A, Vlachogianni T, Fiotakis C (2009) 8-hydroxy-2'-deoxyguanosine $(8 \mathrm{OHdG})$ : a critical biomarker of oxidative stress and carcinogenesis. J Environ Sci Health C Environ Carcinog Ecotoxicol Rev 27(2):120-139

Valko M, Leibfritz D, Moncol J, Cronin MT, Mazur M, Telser J (2007) Free radicals and antioxidants in normal physiological functions and human disease. Int J Biochem Cell Biol 39(1):44-84

Wang L, He X, Bi Y, Ma Q (2012) Stem cell and benzene-induced malignancy and hematotoxicity. Chem Res Toxicol 25(7):1303-1315

Xu G, Ahn J, Chang S, Eguchi M, Ogier A, Han S (2012) Lipocalin-2 induces cardiomyocyte apoptosis by increasing intracellular iron accumulation. J Biol Chem 10 287(7):4808-4817

Yang RY, Hsu DK, Liu FT (1996) Expression of galectin-3 modulates T-cell growth and apoptosis. Proc Natl Acad Sci U S A 25 93(13):6737-6742

Yedjou CG, Milner JN, Howard CB, Tchounwou PB (2010) Int J Environ Res Public Health 7(5):2008-2017

Yuan J, Horvitz HR (2004) A first insight into the molecular mechanisms of apoptosis. Cell 23 116(2 Suppl):S53-S56

Zaidi SA, Shaw AN, Patel MN, Shah W, Rajendran D, Shah BP (2007) Multi-organ toxicity and death following acute unintentional inhalation of paint thinner fumes. Clin Toxicol (Phila) 45(3):287-289

\section{Submit your manuscript to a SpringerOpen ${ }^{\mathcal{D}}$ journal and benefit from:}

- Convenient online submission

- Rigorous peer review

- Open access: articles freely available online

- High visibility within the field

Retaining the copyright to your article

Submit your next manuscript at $>$ springeropen.com 